Универзитет у Нишу, Филозофрски фракултет, Ниш

DOI 10.5937/kultura1339071J

УДК 070.15(497.11)"2013"

32.019.51:070(497.11)

оригиналан научни рад

\title{
СТРАТЕШКА ПОПИТИЧКА
} KOMYHИKALLUAУ

\section{AHEBHOJ ШTAMПИ CPБИJE}

Сажетак: За традиционално новинарство се говорило да грађанима отвара “прозоре у свет". Након открића интернета и бројних конвергентних платформи може се констатовати како је поглед кроз медијске прозоре све замућенији, јер повећағе броја и величине окана рађа сумњу у стварност која се приказује. Анализирајући садржај тиражне и утицајне дневне штампе у Србији, аутор истражује сферу сазнајног комунииирањ а, са фокусом на њен значај у креирању политичке културе. У савременој пракси субјекти јавног мњења су политички актери (од партија до иивилног друштва), власт (од владе до државне администраиије), медији (од масовних до друштвених мрежа), и грађани (од појединаиа до политичке јавности). Штампа у Србији се неумерено посипа златном прашином ПР служби и агенција, посредујући стварност у којој политички естаблишмент неумерено нуди обрасие успеха, спиноване представе о сопственом значају и моћи. После робовањ а у ауторитарном режиму псеудодемократске власти сматрају нормалним да се и оне окористе комуникационим посредницима, форсирајући садржаје којима промовищу све агресивнији политички клијентализам. Променљива природа истине садржана у различитим интерпретацијама реципијената, међу идеолошко и културно различитим читаоцима, води напуштаюу начела новинарске професионалности и преласку у сферу инфозабаве, у којој вести немају карактер јавног добра, већ обичне робе коју поседују најбогатији и најмоћнији појединци.

Кључне речи: итампа, извори информачија, ПР и пропаганда, недостатак дијалога, инфозабава, политичка комуникаиија 
Након класичног парламентаризма ${ }^{1}$ који је доминирао XIX веком и страначке партократије која се усталила током XX столећа, дошли смо до периода демократије јавности, ${ }^{2}$ која je у директној зависности од управљања комуникационим токовима и садржајима. Сфера политичких наука се тихо мења: масовност, социјална структуираност и идеолошка верност у политичким партијама опадају, док се грађани опредељују према интересима који им се у датом тренутку учине најприкладнијим. То значи да људи, чињенице, вредности и догађаји и даље чине саставне делове сваке заједнице, али да тек креирањем медијских значења, конструкција, мишљења и интерпретација добијају политичку видљивост и друштвену моћ. Проблем није релевантан по себи, већ то постаје тек са отварањем дебате у јавном комуникационом простору, па тако битка за његовим надзирањем значи и невидљиву борбу за управљањем друштвом. Медији добијају кључни значај, јер је производња јавног консензуса без њих немогућа, чиме политичка комуникација и симболичка мобилизација постају покретачи јавног мњења. Свест индивидуе се обликује, моделира и прилагођава интересима естаблишмента, али је читав процес невидљив обичном и необразованом посматрачу, који као актер политичког процеса тешко уочава интеракцију политике, безбедности, бизниса и медија. Слике које креирају новинари, ПР службе, агенције за маркетинг или информисање, спин мајстори, лобисти, професионални комуникатори и остали кројачи пропагандног плетива одређују и стратегију политичке комуникације, са циљем да се реалност прилагоди интересима снага које владају.

Управљати неким друштвом значи господарити комуникационим токовима, конфликтним ситуацијама и кризама; једном речју одлучивати о начинима представљања. Артикулација проблема која је у језгру свих јавномњенских процеса у директној је зависности од медијских чувара капија (gatekeeper-a) који одлучују које ће теме постати занимљиве, актуелне, релевантне, важне. Тако долазимо до комуникационог

1 Рад је настао у оквиру пројекта Религија и цивилно друштво, број 179008. који реализују Београдски универзитет, Факултет политичких наука и Нишки универзитет, Филозофски факултет, а који финансира Министарство просвете и науке Републике Србије.

2 Појам је први увео Бернард Манин, који је под њим подразумевао модел представничке власти заснован на "персонализаџији учесника у изборима и успон експерата за политичку комуникаиију, свеприсутност јавног мнења и измештање политичке дискусије из задюих собичака парламентарних одбора или страначких иентрала у медијску јавност"; види у: Manin, B. (1995) Principes du gouvernement reprèsenttatif, Paris: Flammarion 
парадокса: информациона индустрија информише, обавештава, забавља, али и креира софистициран тип друштвене контроле, са лукаво филтрираним обрасцима идеолошке доминације. Демократија је замишљена као идеална заједница равноправних појединаца, грађана који критички спознају свет око себе, али је у међувремену пропаганда бројним техникама и вештинама од њих направила послушне и заведене масе. Карактер новинарства се променио, али мало ко о томе отворено говори: нестале су класе које су створиле институцију независне штампе, тако да нови поредак од информација креира услуге које имају вредност онолико колико недостају обичним људима. Уместо за грађане медији раде за елите, оглашиваче, политичке лидере и партије или власнике медија, и сами постајући део естаблишмента, пристајући да буду адекватно награђени корпоративним новцем или блискошћу са носиоцима моћи. ${ }^{3}$ Структура јавности је промењена, јер су нове технологије, интернет пре свих, али и конвергентне платформе промениле модел комуникативног деловања. Међутим, да би се стратешки циљеви остварили у пракси, неопходно је у просторима јавности конструисати повољне слике о политичким програмима, одлукама и личностима које би требало да их реализују. Стога се у поље јавних информација уводи појам менаимента политичке комуникащије 4 који је саставни део политичких система, без којег нема формулисања, агрегације нити спровођења колективних одлука. Политички простор не постоји без комуницирања, јер је оно у директној повезаности са отвореношћу читавог процеса, па се може рећи да представљање политичких идеја у корену подразумева демократски оквир и подршку јавности. У временима класичних медија производња пристанка ${ }^{5}$ била је једноставнија и ефикаснија,

3 Амерички писац Крис Хеџис (Hedges), некадашњи добитник Пулицерове награде, тврди: “Медији, црква, универзитет, Демократска странка, уметности и раднички синдикати - стубови либералне класе - купљени су корпоративним новцем и обећањима да ће бити убачени близу кругова моћи. Новинари, који више држе до моћника него до истине, објављивали су лажи и пропаганду гурајући нас у рат у Ираку. Медији које хране корпоративни оглашивачи и спонзори, за то време држе невидљивим читаве делове становништва чије би мизерија, сиромаштво и тегобе требало да, принципијелно, буду у фокусу новинарства”, Hedges, C. (2010) Death of the Liberal Class, New York: Alfred A. Knoff, p. 10.

4 Под менаџментом политичке комуникације подразумевамо "планирање, спровођење и контролу комплексних прочеса интерсубјективног преношења садржаја и конструисањ а реалности од стране политичких акmера", Zerfaß, А. \& Oehsen, Н. О. Менаџмент комуникација у политици: основе, процеси и димензије, у: Менаимент политичке комуникащије, (2011) Београд: Konrad Adeauer Stiftung, стр. 11.

5 Ноам Чомски (Noam Chomsky) откривајући пропагандни модел под надзором државне бирократије, региструје пет филтера који цензуришу 
јер је надзирањем штампарија или коришћења електромагнетних фреквенција држава лако обезбеђивала увид, утицај и контролу садржаја који су нуђени пасивној публици. Свеприсутност интернета и хибридних медија већини становништва данас постаје опредељујући фактор у интерпретацији стварности, па се може рећи како свет чињеница све више зависи од значења која им медијски творци креирају, конструишући и реконструишући догађаје, проблеме, конфликте, пријатеље, кривце.

Четири теоријска концепта медија (основни ауторитарни и либертеријански и изведени концепт друштвене одговорности и совјетски концепт пропаганде) ${ }^{6}$ пре више од пола века уважавали су моћ информација у креирању менталних слика, али су њихов манипулативни карактер и персуазивна снага увек приписивани идеолошким противницима. Док је запад у совјетском моделу видео само бирократску ауторитарност и тоталитарну пропаганду, исток је у либертеријанском концепту уочавао заводљивост слаткоречивошћу и прикривеним маркетиншким техникама. Велики прасак на геополитичком простору 1989, укључујући и одлазак комунизма са идеолошке позорнице, обелоданио је пропагандни корпоративни модел који из сенке управља светом. Масовно друштво не чини број становника који живе на истом простору, већ садржај информација које деле, симболички карактер веза које их спајају и вредности које прихватају. Сугестивни утицај порука посредованим медијима индиректно креира листу друштвених приоритета, тако да, временом медији стварају свест о заједничком животу и проблемима. Социјализација без комуницирања није могућа, па се упоредо са развојем нових медијских технологија развија низ стратегија које предвиђају понашања људи у симулираним ситуацијама. Мисли, веровања, стварност и значења у корпоративном добу постају полигон за промовисање имиџа, док се унутар медија развија стратегија придобијања пажње аудиторијума. Ханс Енценсбергер говорећи о надолазећим променама сјајно запажа ко ће држати кормило новог поретка: “Ко је господар, а ко слуга не решава се само на основу тога ко располаже капиталом, фабрикама и оружјем - него

садржај информација: “1) величина, власништво и профитна оријентаиија масмедија; 2) маркетиншко пословање и утицај оглашивача; 3) извори вести; 4) „противваздушна артиљерија“ и напади на медије; 5) антикомунизам као надзорни механизам” Чомски, Н. (2004) Политика без моћи, Загреб: ДАФ, стр. 153-207.

6 У америчкој литератури срећемо и назив “четири теорије штампе”, иако је још у уводном делу један од аутора, професор Вилбур Л. Шрам (Wilbur Lang Schramm), објаснио да под овим тумаче “све медије масовне комуникације". 
што даље, то јасније - ко располаже свешћу других". ${ }^{7}$ Да поједноставимо: људи слике из медија све више прихватају као стварност, не уочавајући трансфер значења међу субјектима, релације друштвених структура са пропагандом или ангажованост консултаната за односе с јавностима.

Управљање догађајима и темама постаје приоритет у политичком ангажовању, јер без одјека у јавном мњењу нема ни друштвеног признања. Свет симбола је у експанзији: проток информација све је гушћи и профилиранији, извори информација све су више усмерени из одређених центара, док појачана редуданција мноштвом технолошких канала компензира буку. Догађаји, проблеми, процеси и дешавања филтрирају се од извора информација, а садржаји и жанрови усмеравају ка унапред одређеним правцима. ${ }^{8}$ Знакови, текстови, тонови, шумови, рекламе, поруке, идеје актуелизују се у одређеном тренутку, из одређене перспективе и из одређених интереса, редукујући стварност у привиде стања, ствари и догађања. Масовни медији данас функционишу као резонантно тло, на којем представници владе и парламента, политичких партија, синдиката, верских организација, универзитета, невладиних организација и других агенаса представљају своје погледе на кризе и начине њиховог решавања. Повећана друштвена диференцијација, плурализација и глобализација мењају традиционални државни оквир (парламент, влада), уводећи у сферу одлучивања и друге агенсе (НВО, синдикате, универзитете, верске организације, лобисте итд.), чинећи комуникацијски пејзаж згуснутијим и колоритнијим.

Истражујући садржај дневне штампе у Србији анализирамо квалитет политичког комуницирања, степен екстерних консултација са економијом, науком и осталим друштвеним сферама, моћ тематизовања и стратешког позиционирања информација (agenda-building), ${ }^{9}$ слику лидера (вођа), као и видљивост извора информација. Циљ нам је да укажемо на промене у комуникационој стратегији, односно да проверимо да ли информације распростиру и идеолошке вредности? То значи да ћемо у раду пажњу фокусирати на текстове, дискурзивну структуру потенцијалних значења и

7 Енценсбергер, Х. М. (1980) Немачка, Немачка између осталог, Београд: БИГЗ, стр. 13.

8 Еделман (Edelman Murray) то каже на другачији начин: “"тишина је пуна значењ а кад означује избегавање проблема који би изазвао поделе ако би био споменут", Еделман, М. (2003): Конструкција политичког спектакла, Загреб: Политичка култура, стр. 37.

9 Ова агенда представља настојање политичких актера да у утицајне медије пласирају за њих најповољније или по њима најважније теме. 
задовољстава, као преносиоце утицаја и произвођаче друштвених потреба.

\section{Методологија}

Квантитативном анализом садржаја осам дневних листова (Политика, Данас, Вечерње новости, Блиц, Курир, Информер, Ало и Наше новине), у периоду од десетог до шеснаестог јуна 2013. године, истраживана су три нивоа медијског комуницирања: садржајни (садржај информације и политички ефекти), структурални (жанрови, извори и токови слања поруке) и процесуални (политичка мотивација и активистички моменти). Кризе се најбоље развијају у друштвима ризика; политичке елите институционализујући јавни простор, паралишу сукобе, моћ и легитимност, не схватајући да тако коче процесе демократизације. У овом тексту истражујемо ниво политичке комуникације у Србији као земљи недовршене транзиције, у тренуцима када се очекује добијање сагласности Европске уније за почетак преговора о чланству. Грађани су опхрвани проблемима очувања сопствене егзистенције и не верују да би се њихово критичко резоновање икако могло тицати доношења политичких одлука. ${ }^{10}$ Разједињена опозиција принуђена је да се бори за сопствени опстанак, економија је скоро уништена, незапосленост свакодневно расте, Косово и Метохија су практично отете територије, па се може рећи како би политички толерантан дијалог могао најавити почетак нове комуникације.

Према неким проценама, ${ }^{11}$ анализиране новине су најтиражније у држави, са значајним утицајем на јавно мњење, па се може констатовати како се политички оквир у доброј мери формира као резултат њиховог писања. У сваком броју анализиран је укупан садржај, без недељних додатака и рекламних материјала као посебних прилога. Јединица анализе били су текстови који су на било који начин, укључујући и изворе информација, обрађивали теме релевантне за јавни комуникациони простор. Истраживање се заснивало на

10 Мирољуб Радојковић сматра да велики број протестних акција, штрајкова глађу, блокада путева и пруга представљају одјек неповерења у делиберацију јавне сфере, јер “моћ политичког естаблишмента не угрожавају масовни медији пошто нису независни", Радојковић, М. (2011) Политичка комуникација у Србији, у: Менацмент политичке комуникаuије, Конрад Аденауер Стифтунг, Београд, стр. 31.

11 Највећу продају бележили су Курир и Блиц (оба листа преко 120.000), затим Вечерње новости (око 100.000), Политика (око 45.000), Наше новине (35.000) и Ало (30.000), док је на зачељу Данас (6.000). Од укупног тиража дневне штампе у Србији (око 600.000 примерака), анализиране новине куповало је више од три четвртине читалаца. (Подаци Прес паблишинг групе, крајем јануара 2012). 
квантитативној и квалитативној анализи укупно 1.314 текстова са политичком тематиком, али подаци нису укрштани на нивоу штампаних издања појединачно!

\section{Теме-хапшена, крађе, корупиија, скандали, плате и пензије}

\section{Европа и понекад Косово}

Свака власт улаже значајне напоре за управљање комуникационим токовима унутар сопственог простора, али то лукаво скрива трудећи се да у јавном простору створи слику о отвореној информационој платформи која одсликава комплексност друштвених односа. Ту имамо два нивоа комуникације: 1) интерну, која је обично у зони аркане, невидљива и нејавна, и 2) есктерну, окренуту опозицији, бирачима, јавности и медијима! Као последицу добијамо појаву персонализације или интензивнију ПР комуникацију, где председник странке или портпароли преузимају на себе бригу за придобијањем пажње и публицитета.

У страначком животу све мање је унутрашњих различитости, а све више дисциплине и лојалности. Тако партије подсећају на велика предузећа која преузимају бригу о страначком запошљавању, егзистенцији, социјалним примањима и слично заузврат очекујући апсолутну послушност и оданост. Појаве дисиденства или унутрашњег критиковања обично се завршавају искључењем или у неким случајевима, оснивањем нових партија, тако да их у Србији у овом тренутку има близу стотину. Схватајући да популарност чине и честа појављивања у утицајним медијима странке, са својим лидерима организују псеудодогађаје, како би обезбедиле присуство репортера и имиџ у јавном мњењу. ${ }^{12}$ Тако службе за односе с јавношћу, небројене агенције, портпароли, лобији, аналитичари, менаџери за односе с јавностима, велике компаније и политички центри преузимају улоге субјеката комуникацијских процеса индиректно угрожавајући аутономност и етичност медијских редакција ${ }^{13}$. Постепено долази до редефиниције новинарске професије, па извештача који одлучује о садржају поруке (decision makers) мења новинар (decision takers) који извршава туђе налоге. Можда и неосетно, новинарство постаје саучесник ПР-а, не уочавајући како

12 Псеудодогађај је планско демавање које се одиграва првенствено због тога да би се о ғему извештавало Agge, Ault and Emery (1988) Introduction to Mass Communications, New York: Harper and Row, стр. 385.

13 Више у: Јевтовић, 3. и Петровић, Р. Јавно мнење и демократски дефицит у добу мултимедија, у: Српска политичка мисао бр. 4, приредио Ђурић, Ж. (2010), Београд, стр. 105-126. 
је лукаво скрајнуто у споредне улице површинског посредовања стварности, политичког блаћења противника (медијски клијентелизам) и запостављања општег добра (public issues). Међу њима нема сукоба јер су на истом задатку, само им се циљеви и методе битно разликују: новинари служе јавности, а ПР-ови клијентима који их унајмљују.

На штампаном тржишту у Србији промена стратегије политичког комуницирања се недовољно уочава. ${ }^{14}$ Говори се о кризи тиража, смањеном броју запослених у редакцијама, паду прихода од великих оглашивача, али скоро нимало о преображају публика, њиховом тихом сељењу ка другим конвергентним платформама, па и о губитку кредибилитета. Комерцијализација, таблоидизација, сензационалност и спектакуларност утичу на смањење озбиљног, истраживачког новинарства, а то се најбоље уочава анализом тема о којима дневни листови извештавају. Бука у комуникационим просторима не спречава појаву диригованог и сензационалистичког дискурса, поготово на насловним странама: Бубало је пао, нека се спреми... (Наше новине, 15. јун), претпоставка невиности скоро и да не постоји: Бубало ухапшен, Беко опкољен, уз наднаслов: То, народна милицијо, нови удар на државне лопове (Информер, 15. јун), најчитанији Блиц иде и корак даље. Уз велику фотографију преко целе стране даје и пикантне детаље: око хапшења: Бубало у шоку, Мрђу ухапсили на кафи с Беком (15. јун), док традиционална Политика исправно објављује, такође на насловној страни: Бубало главни осумњичени за спорну приватизацију „Луке Београд“. Сензационализму није одолео ни озбиљни Данас, који у првом плану читаоце информише како ће $C p n$ ске институичје бити у систему Косова до краја 2013, а онда објављује и мању фотографију и текст са наднасловом: Ухапшен Предраг Бубало, али и тврдњом у наслову: Траг води до Бека и Мишковића, иако за то у тексту нема доказа. Колико су таблоиди у Србији оруђе у рукама политичких обрачуна показују и честе најаве хапшења, некада тачне, а некада и као празни пуцњи. ${ }^{15}$. Пре стварног догађаја у неким

14 Препознатљиве су три стратегије: Top down (одозго надоле), која у средиште ставља политику и центре моћи; стратегије демократске јавноcmu, са медијима у центру, и стратегија Bottom ир (одоздо нагоре), где прилику добијају обични грађани.

15 Типоване информације (tip-offs), с обзиром на непоузданост извора, често умеју да буду лажне или манипулативне, у складу са интересима појединих лоби група. У великим редакцијама све чешће се запошљавају контролори информација (fact checkers), чији је задатак пажљиво проверавање свих изјава, исповести, докумената, писама, спискова, мејлова, података... Глад за брзином никада не сме бити снажнија од глади за истином. 
таблоидима објављена је најава хапшења: Данас пада Бубало (Ало, 14. јун, насловна страна) или Падају крупне зверке: Хапшења, полииија приводи одговорне због луке Београд (Курир, 14. јун), што само показује спрегу новинара, безбедносних служби и власти. Епилози овако “значајних” тема скоро да изостају или се објављују на унутрашњим страницама, на маргинама пажње (Бивии градоначелник Краљева пуштен из притвора - објавио само Данас, 13 јуна, иако се на слободи уз бившег функционера нашло још 15 лица осумњичених за злоупотребу средстава за санацију објеката после земљотреса који је 2010. погодио овај град).

Друштво у транзицији инструментализује новинарство, сматрајући да провоцирањем медијске пажње кроз псеудополитичке спектакле осваја подршку јавности. Власт се представља као жестоки противник мафије, криминала и корупције, па откривањем афера спинује ${ }^{16}$ јавно мњење. Рефлектори пажње се фокусирају на сам чин хапшења која се одвијају пред камерама ТВ екипа или репортера одабраних новина, да би временом пажња јавности попуштала, без конкретног решења или адекватне казне. Штампа на насловницама саопштава како је министарство здравља отказало куповину опреме вредне 300 милиона - Намештен тендер за куповину скенера (Блиц, 11. јун), даје сензационалну информацију о последњој понуди најбогатијег Србина - Мuшковић нуди 25 милиона евра за слободу (Наше новине, 12. Јун), што логиком крда преузимају чак и озбиљни медији (Данас, 12 јун, стр. 5). Спектакуларност и сензационалност провоцирају критички опрез маса јер трансформишући стварност нуде драмски конфликт којим се придобија подршка обичних људи. Један проблем се теоријом агенде уводи у политичку орбиту, како би се јавност забављала његовим рефлексијама које у великим количинама пристижу, обично из “анонимних”, али “добро обавештених" извора. Низови информација ређају се као ватромет, а учесталошћу понављања ударних података напетост расте. Причу преузимају други медији, па се тако низовима произведених слика и значења, креира друштвени проблем, који по потреби, може да се представи као безбедносна претња заједници или велики успех власти. Док се јавно мњење бави наметнутим сликама и решењима, иза паравана, политички лидери решавају виталне проблеме, растерећени бриге о притиску

16 Под овим појмом подразумевамо дефиницију Џона Малтеса (John Maltese): спиновање је “промишьено стварање нових периепиија и покушај контроле политичких реакиија" Maltese, J. (1994) Spin Control. The White House Office of Communications and the Menagement of Presidental News, Chapel Hill: The University of North Carolina Press, p. 215. 
шире заједнице. Пажња јавности јача или слаби, асиметрично са медијским конструисањем проблема, сенчењем догађаја и стављањем тежишта на различите аспекте. Велики проблем може бити релативизован као мали, али и обрнуто. Пумпање афера, дозирање стварности техникама шокирања и спиновања, мали су део богатог инструментарија којим се управља емоцијама маса. Након одређеног времена, када се публика засити наметнутом темом производи се нова, још спектакуларнија, заводљивија, необичнија, и тако у круг. Један проблем замењује други, стару слику потискује нова, а дневне потребе за вестима се задовољавају информацијском олујом. Кризе и проблеме стварају и разрешавају људи, па тако политички систем можемо посматрати као мизансцен, креиран по вољи невидљивих владара. Свака порука пренета масмедијима део је симболичке презентације стварности, а сложени свет знакова, икона и слика остварује функцију комуникабилности, без које спектакл не би имао политичку снагу.

Партије све више развијају интегративну функцију са државом, при чему борба са политичким противницима нема граница. Штампа на насловним странама информише јавност како је Пуч у ДС пропао, Тадић није срушио Биласа, али исто тако и о Побуни у СПС, траже се смене Бајатовића и Мркоњића (Наше новине, 10. јун); из ње сазнајемо да Вучић са Чедом руши Ђиласа (Ало, 13 јун) или да су се Посвађали Вучић и Динкић (Блиц, 12. јун), док Курир у серији текстова руши ауторитет председника највеће опозиционе странке и градоначелника Београда: Доказ о Ђиласовим милионима (11. јун), Ђиласе, давао си мито да би згрнуо милионе (12. јун), Хвали се учинком, а задужио град за 900 милиона евра (13. јун), Жељко Митровић: Открићу како је Ђилас пљачкао (14. јун), Билас хоће да замени Динкића (15. јун), Сукобили се Жељко Митровић и НУНС: Смем ли да објавим да је Ђилас хапсио лекаре (16. јун).

Игра односа у јавном простору све је очигледнија, поготову ако се зна начин на који медији функционишу. Посматрајући информацију као робу, а не услугу, власници форсирају садржаје који се допадају управљачким центрима, па тако страначке промене у политици не значе драматичан начин промене јавне комуникације. Сматрајући медије као технолошка средства која сада служе њиховим интересима, победници преузимају методе и технике поражених снага. Тако се тензије непрестано одржавају и подстичу, појавна слика о другима приказује се најмрачнијим бојама, а истовремено хиперболизује и апострофира сопствени допринос. Партије у Србији, временом, постају предузећа за пружање 
услуга, док је основни мотив за учлањење користољубље, односно лични, а не идеолошки интерес. Отуда социјалне теме у секундарном пољу: 75 губиташа на распродаји (Beчерње новости, 11. јун); Кредити грађане гурају у ропство (Вечерње новости, 13. јун), Запањујућа лакоћа пљачкања државе (Вечерње новости, 14. јун), Од богатих нема ни вајде, нити пореза (16. јун), Прете нестабилност и економски суноврат (Данас, 11. јун), Зараде и пензије неће бити замрзнуте (12. јун), Половина родитеља не плаћа алиментацију (Политика, 10. јун), Хитне антикризне мере због нереалног буцета (13 јун). Некако стидљиво провлаче се и најаве промене статуса у јужној српској покрајини: Гасе се канцеларије МУП-а на северу Косова (Политика, 14. јун) или Власт је коначно почела системски да мисли о Косову (Данас, 15. јун).

Табела 1. Укупан број текстова политичке природе повезаних са Србијом:

\begin{tabular}{|l|l|l|l|l|l|l|l|l|l|}
\hline Рубрика & Политика & Данас & $\begin{array}{l}\text { Вечерње } \\
\text { новости }\end{array}$ & Блич & $\begin{array}{l}\text { Наме } \\
\text { новине }\end{array}$ & Курир & Информер & Ало & укупно \\
\hline $\begin{array}{l}\text { Политика, } \\
\text { друштво } \\
\text { догађаји } \\
\text { дана... }\end{array}$ & 165 & 158 & 84 & 138 & 46 & 76 & 47 & 52 & 766 \\
\hline $\begin{array}{l}\text { Криминал, } \\
\text { хапшења }\end{array}$ & 9 & 4 & 17 & 25 & 36 & 42 & 18 & 14 & 165 \\
\hline $\begin{array}{l}\text { Социјалне } \\
\text { теме }\end{array}$ & 22 & 27 & 67 & 21 & 13 & 77 & 13 & 9 & 189 \\
\hline $\begin{array}{l}\text { Европска } \\
\text { унија }\end{array}$ & 14 & 16 & 11 & 12 & 5 & 11 & 8 & 5 & 82 \\
\hline $\begin{array}{l}\text { Косово } \\
\text { Метохија }\end{array}$ & 17 & 12 & 31 & 15 & 4 & 12 & 9 & 12 & 112 \\
\hline
\end{tabular}

Избор тема које ће се пратити, страница на којој ће се текст налазити, начини приказивања политичких лидера и странака, њихов изглед на фотографијама, контекст и тон којим се догађај анализира, као и многа друга средства презентације могу битно усмеравати ставове читалаца. Готово све значајније политичке партије у Србији ангажују спин мајсторе или професионалне комуникаторе који им стратешки срачунато саветују како да управљају информацијама, фокусирајући се на персонални успех и личну популарност. Настанком партијских, специјализованих агенција или одељења за политичко комуницирање мења се и садржај штампе која податке и теме све чешће добија из стратешких центара, са планом да се селекцијом тема и саговорника дефинишу идеолошки обрасци и политички актери. Јавном презентацијом њихових ставова, идеја, мисли, исказа и веровања читаоци се усмеравају ка идеолошком циљу. То је теорија фреминга (Theory of Framing), која подразумева селекцију и истицање 
само одређених делова опажене стварности, у складу са интересима снага које управљају друштвом.

\section{Златна прашина ПР-а}

У савременом друштву уочљива је појава президенцијализащије партија, односно медијска легитимизација лидера и осталих чланова тима. Класичан облик партијског комуницирања се губи, нови комуникациони токови модернизују масе, тако да брзо, усмерено и таргетирано информисање оставља утисак на аудиторијум. Значајно обликујући дневну агенду, владајуће партије у комбинацији са државним институцијама и носиоцима власти сужавају простор за другачије идеје и програме, критичке гласове и плуралистичку комуникацију. Политичка култура настаје као резултат доминантних уверења, ставова, идеолошких вредности и образаца, али њена моћ је у креирању комуникационих стратегија и тактика којима ће јавност дати пристанак ${ }^{17}$. Утицај цивилног друштва у Србији је готово занемарљив, док је присуство опозиционих партија и јавних расправа маргинализовано. Ко говори, а ко ћути у штампи, један је од најбољих индикатора друштвене равноправности.

Од укупно 1.373 анализирана прилога влада, министарства, државне институције (20,32\%), политички лидери (24,32\%), председник државе $(3,35 \%)$ и политичке партије $(11,28 \%)$ доминирају као извори информација у готово свим утицајним дневним новинама Србије, што је блиско резултатима сличне анализе. ${ }^{18}$ Додамо ли овима податак о директним информацијама пристиглим од ПР служби и агенција за испитивање јавности (7,5\%), схватићемо колико је велики утицај партија на власти које чврсто контролишу укупан медијски простор (66,77\%). Мења се карактер партија: уместо масовности и класне базе потенцира се на пропаганди и маркетиншком праћењу активности, чак и на њиховом креирању. Све већи број информација резултат је претходно обрађених саопштења за јавност или спинованих информација произведених у владиним бироима за односе с јавношћу, достављених од портпарола и сличних служби, док је у порасту и број интервјуа реализованих телефонским позивима. Тржишна оријентација новинарства намеће нови императив: стварати што више вести, интервјуа и сличних жанрова са што мање трошкова, па привидно “бесплатни”

17 Више у: Јевтовић, 3. (2007) Масмедијски преображај тероризма и религије у глобалном поретку, Политикологија религије бр. 1, Београд, стр. 97-124.

18 Види: Јевтовић, 3. и Арацки, 3. (2012) Новинарство или ПР - стварност или привид, Култура бр. 136, Београд, стр. 262-279. 
пакети података и фотографија који сваког тренутка стижу у редакције постају моћна оруђа у обради јавног мишљења. Програми партија губе на значају, разлике су све тананије, док се руководства професионализују на нивоу организационих целина које политичке идеје дисеминирају медијским токовима. Службени извори тако неосетно врше надзирућу функцију, без бојазни да ће их неко прозвати за кршење људских права. Академски стручњаци или обични грађани постају део икебане о отворености комуникационе заједнице $(10,26 \%)$, док о утицају цивилног друштва у Србији за сада нема ни говора $(11,58 \%)$.

Табела 2. Извори информација:

\begin{tabular}{|l|l|l|l|l|l|l|l|l|l|}
\hline Извори & Политика & Данас & $\begin{array}{l}\text { Вечерње } \\
\text { новости }\end{array}$ & Блич & $\begin{array}{l}\text { Наме } \\
\text { новине }\end{array}$ & Курир & Информер & Ало & укупно \\
\hline $\begin{array}{l}\text { Влада, } \\
\text { министарства, } \\
\text { државне } \\
\text { институције }\end{array}$ & 56 & 42 & 51 & 45 & 12 & 25 & 27 & 21 & 279 \\
\hline $\begin{array}{l}\text { Председник } \\
\text { државе }\end{array}$ & 8 & 6 & 11 & 6 & 4 & 5 & 4 & 2 & 46 \\
\hline $\begin{array}{l}\text { Политички } \\
\text { лидери }\end{array}$ & 46 & 28 & 32 & 55 & 24 & 43 & 63 & 43 & 334 \\
\hline $\begin{array}{l}\text { Политичке } \\
\text { странке }\end{array}$ & 16 & 21 & 23 & 25 & 12 & 18 & 19 & 21 & 155 \\
\hline $\begin{array}{l}\text { Инострани } \\
\text { извори }\end{array}$ & 32 & 29 & 19 & 17 & 14 & 18 & 16 & 11 & 156 \\
\hline $\begin{array}{l}\text { ПР службе, } \\
\text { Агенцје } \\
\text { испитивање j. } \\
\text { Мњења }\end{array}$ & 11 & 14 & 12 & 19 & 11 & 9 & 14 & 13 & 103 \\
\hline $\begin{array}{l}\text { Представници } \\
\text { јавних } \\
\text { организација, } \\
\text { удружења, } \\
\text { цркве... }\end{array}$ & 23 & 19 & 16 & 35 & 11 & 26 & 17 & 12 & 159 \\
\hline $\begin{array}{l}\text { Академски } \\
\text { стручњаци, } \\
\text { обични } \\
\text { грађани }\end{array}$
\end{tabular}

Интереси власти су врло јасни: стављајући новинарима на располагање низове информативних садржаја оне софистицирано намећу агенду дневног реда, лукаво утичући на креирање јавности и њено мишљење о одређеном проблему. Институционална легитимност се јавља као последица симболичке моћи коју поседују високи владини функционери (министри, владини службеници, портпароли, директори институција и сл.), који реално имају снагу јавног утицаја. Суштина је у наметању тема и рутинском стварању псеудодогађаја (производња афера, политичких изјава, конференција за штампу, парламентарних подела итд.), тако да публика лаковерно гута удицу, не примећујући да слободно време жртвује причама које су створили други. Државне елите се у пракси сматрају поузданим изворима информација, па често добијају предност у извештавању. Истовремено, редакције у медијима су све малобројније, јер тржишна 
оријентација, смањење трошкова, ризици пословања и трка са временом придоносе затварању у канцеларије, претварајући новинаре у интерпретаторе пристиглих саопштења, изјава и достављених информација. Уважавајући чињеницу да највећи део ПР службеника чине бивши новинари, који су савршено научили вештине и технике новинарског писања јасно је што се редакције ослањају на понуђене информације. Анализа прилога у Њујорк Тајмсу открила је снажно ослањање на службене изворе: од 57,2\% до 72,5\%, ${ }^{19}$ што је потврђено и овим истраживањем. Златна прашина ПР-а све више добија на значају: она је тиха, готово невидљива, али увек присутна да, нијансираним симболичким значењима, да пројектовану боју, интензитет, снагу и смер. Она не дозвољава сумњу, јер увек нуди скривени кључ за разумевање појмова или процеса, наравно, увек у интересу клијената који су платили за њено расипање по новинским ступцима и сликама. Она, по правилу, не говори аудиторијуму Шта да мисли (то је привидна слобода објекта), већ јој нуди $\mathrm{O}$ чему да мисли (прикривена моћ субјекта), развијајући поверење, пажњу и прихватљивост. Златна прашина се посипа само по истинитим информацијама, али тако што полира њихов сјај, истичући само оно што одговара елитама. Политичка ефикасност се не мери количином информација које су понуђене јавности (буком), већ убедљивошћу пренетих идеја, а то jе већ посао за професионалне службе и тимове.

\section{Лидер кампањь}

Јирген Хабермас поред политичке и друштвене моћи, потенцира значај медијске моћи као специфично новог капитала у јавној арени, стратешки битног за функционисање плуралистичке заједнице. У нормативну теорију први уводи појам делиберације, ${ }^{20}$ објашњавајући да интеракцију између државе и њених друштвених окружења омогућавају комуникациони канали који филтрирају политичке захтеве и идеје. Халабуку негдашњих изборних кампања вођених по трговима и стадионима, акција од врата до врата бирача, сменила је чудесна опсена медијских слика које омогућавају демократску легитимацију неког друштва. Отуда председнички

19 Zhang, J. and Cameron, G. T. (2003): Study Finds Sourcing Patterns in Wen Ho Lee Coverage, Newspaper Research Journal 24 (4), p. 96.

20 Делиберативна демократија је модел у којем се политичке одлуке доносе процесом преговарања, договарања и убеђивања. Она је резултат комуникационог деловања између формално организованих и неформалних делиберација лицем у лице, у аренама и на врху и на дну политичког система, Хабермас, J. (2007) Политичка комуникација у медијском друштву, ЦМ, Нови Сад: Протокол, Београд: Универзитет у Београду, Факултет политичких наука, стр.11. 
кандидати као телешоп производи, изборне кампање као углађени холивудски филмови, а политички капитал као резултат примене метода корпоративног комуницирања.

У политичкој пропаганди посебно значајно место заузима тзв. лидер кампања. Њен циљ је да, јавним истицањем, фаворизовањем, хваљењем, подршком, величањем и сличним, подржи одређену личност, мада у негативном контексту (сатанизацијом, вређањем, ружењем, мимикријом, пежоративношћу и сличним представама) може имати и контраслику о некој важној личности (шефу државе, вођи политичке странке, јавној личности која не дели жељене идеје). Међу актуелним српским политичарима визуелно доминирају Ивица Дачић 16,25\%, Млађан Динкић 14,65\%, Томислав Николић 14,25\% (овај проценат је увећан чињеницом да је само у једном броју новина Ало, 16. јуна, објављено 15 фотографија у форми албума) и Драган Ђилас 15,75\%, а изненађује мања видљивост Александра Вучића $(8,45 \%)$. Међутим, када се анализира контекст лако се уочава да су фотографије премијера и министра полиције (Дачића) и министра финансија и привреде (Динкића) често са негативним публицитетом, у илустрацији коруптивних афера и са лукавим указивањем на њихову блискост са актерима (Дачићева фотографија је на насловној страни листа Ало, од 14. јуна: Изгубила менструацију због Дачићевог сарадника, иако се у тексту пише о злостављању секретарице од стране високог функционера МУП-а, или текст: Лидери коалиције данас о платама и пензијама: Дилема - да ли повећати пензије за 125 динара, илустрован је фотографијом дубоко замишљеног Дачића, чиме се сугерише његова одговорност. У међувремену, фотографије вицепремијера Александра Вучића одишу смиреношћу, озбиљношћу и активизмом. Ако има друштво онда су то високи функционери Европске униje, а у неким примерима слике ухапшених особа се везују са мањом фотографијом председника владајуће странке, чиме се у подсвест аудиторијума усађују његове заслуге у обрачуну са криминалом. У политичкој пропаганди постоји низ техника заснованих на визуелизацији садржаја, при чему је потребно у дужем и континуираном периоду у медијима понављати сличне информације и слике како би се садржај подсвесно задржао код реципијената. Пажњу медија изазвало је и хапшење некадашњег министра Предрага Бубала, тако да је релативно висока заступљеност фотографија (6,23\%) резултат хапшења које се догодило.

Штампа у Србији не зна за морал нити професионалну етику, а стратешке ресурсе чини структура често сензационалистичких порука које се распростиру мрежом. Њен 
задатак није само да обавештава, већ и да креира слику о неким личностима, па и по цену напуштања професионалних стандарда. Насловна страна једног таблоида, уз додатак: Ексклузивно наднаслов: Драма у Багдаду, и наслов преко целе стране: - Веља преживео бомбашки напад, ислустрована је шокантном фотографијом разрушених зграда и људи у паници. Новинар даље детаљније објашњава како је бомба експлодирала “тик уз зграду у којој се одржавао састанак ирачко-српске делегације", иако се у стварности догађај збио на удаљености од неколико стотина метара, без икакве опасности по учеснике. Министар грађевине се представља као храбар, одговоран и скроман човек (“није било места за страх, ми смо радили наш посао...”), који уз то остварује изврсне резултате, што се истиче антрфилеом: (“планирани велики инфраструктурни објекти: 42 пројекта за станоградњу, изградња 27 мостова, изградња 800 километара аутопута.......”). Текст коинцидира са контекстом најављене реконструкције владе, па га треба посматрати као лоше обављени ПР.

Уместо комерцијалним оглашавањем, политичке странке и неформални центри моћи кроз информативне садржаје које аудиторијум прати с мање опрезности, воде своје кампање, остварујући комуникациони утицај. Медији им служе као огласне табле, па се сваки ред у новинама, секунда на радију или телевизији да измерити финансијским еквивалентом. "Као и код огласне противвредности, и овде оглас замењујемо одговарајућим медијским прилогом и долазимо до бројке коју онда можемо успоређивати с одговарајућим бројкама из неког комериијалног ценовника". ${ }^{21}$ Управљање јавношћу заснива се на мерењу потенцијалне запажености (енгл. oportunity to see) тако да озбиљне информативне службе медијски планирају повећање публике које ће организовањем псеудодогађаја уследити. Да би се повећао сопствени маневарски простор приступа се блаћењу противника тако што се производи ланац догађаја са негативним публицитетом. Новина Информер, током анализиране седмице у центру интересовања, има високо позиционирану личност из владајуће коалиције: Ексклузивно: Истина о пљачки века, наслов: Ево доказа; и поднаслов: Стопирана истрага о Динкићу, Кипру и милијардама (10. јун); сутрадан се објављује деманти министра финансија, али уз коментар редакције: Млађан је много нервозан (11. јун), већ наредног дана министар је враћен на насловну страну: Министар у невиђеном страху: Послао жену у полищију да се распита о истрази

21 Верчић, Д., Заврл, Ф., Ријавец, П., Верчић, А. Т. и Лацо, К. (2004) Односи с медијима, Загреб: Масмедиа, стр. 155. 
(12 јун), тема је и даље у жижи интересовања ових новина: Динкић не може да уцеюује, али се у причу увлачи и премијер Ивица Дачић (13. јун), обрачун добија драмске елементе: Млађан Динкић - Уништићу Информер (14. јун), да би се серија написа у читавој недељи завршила коментаром уредника: Или Динкић или Србија (15. јун). Јавност директно погађају приче о корумпираности, везама са подземљем, криминалним радњама, националној издаји и сличном јер она слику о политици креира посредством информација које јој саопштавају медији. Када медији политичке актере прикажу као сумњиве, негативце или политичке аутсајдере, опада поверење у њихову компетентност. Покушаји да се кредибилитет поврати изласком у јавност (енгл. going public), ${ }^{22}$ организовањем конференција за штампу, давањем интервјуа или демантија, претњама тужбама и сличним актима имају бумеранг ефекат, односно само враћају негативни публицитет. Контрастратегија се крила у пласирању веродостојних информација конкурентским медијима, чиме би се повратило поверење публике.

Тематизација одређеног проблема само је једна од фаза у стратегији мобилисања јавног мњења. Подршка јавности обезбеђује се увек континуираном пропагандом, која се у време изборних кампања само појачава. Размислите зашто једна од најмоћнијих компанија на свету Кока кола толико улаже у маркетинг, иако је број један у свету безалкохолних пића. Да би и остала на тој позицији, она мора стално да улаже у представе о сопственој моћи и квалитету, јер ако то не би радила на њено место би брзо дошли други. Стратегија која у средиште друштва ставља медије подразумева притисак на јавност, јер оријентире и смерове понашања креирају гласови видљиви у средствима јавне комуникациje. Политички живот све више артикулишу професионалне службе за информисање и публицитет, док личност лидера и његовог тима постају центар информационог деловања. ${ }^{23}$ Персонализацијом друштвених активности они државне активности усмеравају ка партијским акцијама, нудећи аудиторијуму да трансфером значења изграде своје ставове и опредељења.

22 Kernell, S. (1988) Going public: New Strategies of Presidential Leadership, Washington: CQ Press

23 Види у: Sarcinelli, U. (2007) Partelenkomminikation in Deutschland: zwischen Reformagentur und Reformblockade, in: Reformen kommunizieren, Herausforderungen an die Politik, Weidenfeld, Gütersloh: Bertelsmann Stiftung, p. 109-145; Uwe, J. (2004) Der Wandel der Parteien in der Mediendemokratie. SPD und Labour Party im Vergleich, Frankfurt 
У анализираној штампи евидентно је непоштовање провере тачности информација. Чак у $56,25 \%$ свих текстова коришћен је само један извор, у $8,75 \%$ извора нема нити се могу препознати, тако тек нешто више од трећине текстова задовољава професионалне стандарде. Ако то комбинујемо са високим приливом информација из званичних извора (државе односно владе, председника, министарстава, политичких партија, лидера и професионалних служби за ПР и информисање), закључићемо да је значајан део садржаја дискретно креиран од центара власти. Ако се поштује старо новинарско правило да свака информација мора имати најмање два независна извора, онда из емпиријских података произилази констатација да је садржај српске дневне штампе врло непоуздан и превише идеологизован.

\section{Закључна разматрана}

Друштва у транзицији немају стабилне политичке базе, што се у Србији свакодневно може пратити пребезима читавих одбора или угледнијих појединаца који, ради личних интереса, мењају партијску припадност. Пошто странке тешко контролишу сопствено чланство, у први план избијају стратегије којима се осваја подршка јавности, док лидери мобилишу гласаче перманентним утицајем на креирање информативне агенде. Тако штампа губи статус заштитника грађана, промовишући идеје владајућег естаблишмента, па се и таблоиди све више баве политичким спиновањем, напуштајући традиционални теоријски оквир деловања (естрада, забава, трачеви...). Ерозија професионализма је евидентна, све је више вести без проверених извора, док монопол тема наметнут од власти угрожава и идеју постојања политичког дијалога. У медијима се одвија тиха битка за публицитетом, док носиоци његовог преусмеравања и расподеле, уместо новинара, све чешће постају ПР службе, менаџери за управљање јавностима, спин мајстори, лобисти и слична одељења за креирање свести.

\section{ЛИТЕРАТУРА:}

Agge, Ault and Emery (1988) Introduction to Mass Communications, New York: Harper and Row

Верчић, Д., Заврл, Ф., Ријавец, П., Верчић, А. Т. и Лацо, К. (2004) Односи с медијима, Загреб: Масмедиа

Зерфас, А. и Охсен, Н. О. Менаџмент комуникација у политици: основе, процеси и димензије, у: Менаимент политичке комуникаuиje, (2011) Београд: Konrad Adeauer Stiftung

Zhang, J. and Cameron, G. T. (2003): Study Finds Sourcing Patterns in Wen Ho Lee Coverage, Newspaper Research Journal 24 (4) 


\section{ЗОРАН ЈЕВТОВИЋ}

Еделман, М. (2003): Конструкција политичког спектакла, Загреб: Политичка култура

Енценсбергер, Х. М. (1980) Немачка, Немачка између осталог, Београд: БИГЗ

Јевтовић, 3. (2007) Масмедијски преображај тероризма и религије у глобалном поретку, Политикологија религије бр. 1, Београд

Јевтовић, 3. и Петровић, Р. Јавно мнење и демократски дефицит у добу мултимедија, у: Српска политичка мисао бр. 4, приредио Ђурић, Ж. (2010), Београд

Јевтовић, 3. и Арацки, 3. (2012) Новинарство или ПР - стварност или привид, Култура бр. 136, Београд

Kernell, S. (1988) Going public: New Strategies of Presidential Leadership, Washington: CQ Press

Maltese, J. (1994) Spin Control. The White House Office of Communications and the Menagement of Presidental News, Chapel Hill: The University of North Carolina Press

Manin, B. (1995) Principes du gouvernement reprèsenttatif, Paris: Flammarion

Радојковић, М. (2011) Политичка комуникација у Србији, у: Meнаимент политичке комуникаичје, Конрад Аденауер Стифтунг, Београд

Чомски, Н. (2004) Политика без моћи, Загреб: ДАФ

Чомски, Н. (2006) Контрола медија - спектакуларна достигнућа пропаганде, Нови Сад: Рубикон, Београд: Беокњига

Хабермас, J. (2007) Политичка комуникација у медијском друштву, ЦМ, Нови Сад: Протокол, Београд: Универзитет у Београду, Факултет политичких наука

Hedges, C. (2010) Death of the Liberal Class, New York: Alfred A. Knoff 


\title{
ЗОРАН JEВТОВИЋ
}

\author{
Zoran Jevtović \\ University in Niš, Faculty of Philosophy, Niš
STRATEGIC POLITICAL COMMUNICATION IN SERBIAN DAILY PRESS

\begin{abstract}
It was said for traditional journalism that it opened ,windows into the world" to the citizens. After introduction of the Internet and a vast number of convergent platforms one could argue that the gaze through these media windows is becoming more and more blurred, due to a continually increasing number and size of such windows, which gives raise to suspicion as to the depicted reality. Analyzing contents of the most investigated daily newspapers in Serbia, the author has invastigated the realm of epistemic communication with special attention paid to its role in the process of forming political culture. In contemporary practice, the creators of public oppinion are political figures (ranging from political parties to civil society organizations), those in power (members of Government and state administration), the media (from mass media to the social networks) and citizens (from individuals to the political public). Serbian press allow themselves to be gold dusted by PR agencies, presenting reality as patterns of succes promoted by political establishment and spinned by manifestations of significance and power. In the aftermaths of the authoritarian pseudo-democratic regime, it is considered normal for political establishment members to use communication intermediaries to serve their interests, thus forcing the contents suitable for aggressive promotion of political clientelism. Unstable nature of the truth provided in various interpretations of recipients, among ideologicaly and culturally different readers, leads to abandoning of professional principles in journalism and their substitution with informative\&entertaining contents. Within this context, news are losing their character as a public value and are becoming merchandise instead, possesed by the richest and most powerfull individuals.
\end{abstract}

Key words: daily press, information sources, $P R$ and propaganda, lack of dialogue, infoentertainment, political communication 